\title{
Dynamics of Integration and Economic Growth of the West African Economic and Monetary Union (WAEMU)
}

\author{
Sayouba Ouedraogo, Désiré Drabo \\ Economics Department, University Ouaga 2, Ouagadougou, Burkina Faso \\ Email: sayoubaoued@yahoo.com, souedraogo@univ-ouaga2.bf
}

How to cite this paper: Ouedraogo, S. and Drabo, D. (2019) Dynamics of Integration and Economic Growth of the West African Economic and Monetary Union (WAEMU). Modern Economy, 10, 1121-1133. https://doi.org/10.4236/me.2019.104076

Received: February 18, 2019

Accepted: April 7, 2019

Published: April 10, 2019

Copyright $\odot 2019$ by author(s) and Scientific Research Publishing Inc. This work is licensed under the Creative Commons Attribution International License (CC BY 4.0).

http://creativecommons.org/licenses/by/4.0/

\section{(c) (i) Open Access}

\begin{abstract}
The objective of the study is to determine the effect of the dynamics of regional integration on economic growth in the West African Economic and Monetary Union (WAEMU). The autoregressive vector analysis using the Cholesky decomposition used data from the Central Bank of West African States, United Nations Conference on Trade and Development statistics, and world development indicators. The results show that the overall contribution of a WAEMU country to integration accounts for $0.5 \%$ of the variation in growth in the community area over the long term. The effects of the free trade area and the customs union are respectively higher on economic growth than economic union and economic and monetary union. The establishment of an effective free trade area would lead to better economic growth. In addition, taking the common market into account would more than capture the contribution of the integration process to economic growth and would be a prospect for future research.
\end{abstract}

\section{Keywords}

Economic Growth, Impulse Function Response, WAEMU

\section{Introduction}

Economic integration aims at the adoption of a common currency and the opening of the economic markets of the member countries of the group and proceeds through the creation of a free-trade area, a customs union, a common market, and an economic and monetary union. Increasing the size of an economic market through economic integration would have positive effects on economic growth. The process of regional integration becomes an instrument of 
economic policy and a result to improve the living conditions of the inhabitants [1]. The theory has established the relationship between integration and economic growth [2] [3]. The main channels through which integration stimulates economic growth are the stimulation of trade through the removal of barriers and the attraction of foreign direct investment [4] [5]. However, the questioning of collaboration between the countries of an economic and monetary union, such as Brexit, the Trans-Pacific Treaty, the North American Free Trade Agreement (NAFTA), and the Southern Common Market (Mercosur), would certainly be explained by the fact that the negative effects of the agreements would outweigh the positive effects. The rise of national selfishness is a reality in many countries with decades of common currency. The upsurge of protectionism is taking place in a context of increasing inequalities and the deterioration of citizens' trust in their institutions [6]. Migration phenomena from the south to the developed countries in the north and the internal macroeconomic imbalances (increasing public and private debt) and external (trade deficit) imbalances have increased. Austerity plans have become widespread, and the sacrificed middle classes in developed countries threaten to bring to power populist, xenophobic, authoritarian parties and supporters of protectionism and ethnic retrenchment on ethnic grounds. Isolationism and nationalism are more valued [7]. The magnified effects of free trade on economic growth in the context of an optimistic, trade-based globalisation would hardly be acceptable to all countries. The hope of openness for economic growth and opportunities would seem to become constraints, confinement, and despair. The almost unanimous view that cooperation and mutual trade for the benefit of all as a source of progress is pushed aside by the dislocation of economic groupings. The individual primacy of each country seems to take precedence over the desire to organise and integrate for a community of countries. The observed downturns have their roots in negative economic aspects precisely because of this collaboration based on economic integration. These perhaps cyclical difficulties mainly concern countries outside of Africa.

In Africa, recent or emerging supranational organisations are, in this global context, reflecting the development model "a country is stronger when it is alone". Economic groupings, such as the West African Economic and Monetary Union (WAEMU), raise questions about the outcome of the phases of the process of building integration. Indeed, the success of WAEMU requires positive effects in terms of economic growth [8]. However, achieving the best economic results remains a challenge to improve people's well-being. The countries of WAEMU are facing poverty, food insecurity, environmental degradation, degradation of natural resources, and precarious communication and transport infrastructure. However, their gross domestic products (GDPs) have a positive evolution and have a positive effect on trade. These exchanges are significantly influenced by membership of the WAEMU common monetary zone and the implementation of reforms on economic integration [9] [10]. Work on sub-regional integrations shows the development of trade and trade flows between the coun- 
try parties [11] [12] and [13]. Inflows of foreign capital support economic growth. The elimination of controls on capital movement is conducive to growth [14]. In addition, [8] looked at the process of economic regionalisation and the different sources of endogenous growth. The reasons for the divergence of the GDP of WAEMU countries were analysed by [15]. The relationship between taxation and economic growth has been studied by [16]. Property rights, corruption, and economic growth have been [17] concerns. The inadequacies of these studies are the rather limited nature of the time series related to the data, the use of erroneous specifications and heterogeneous economic samples, omitted variables, the time and study period, and the existence of threshold effects [18] [19]. Moreover, the effects of the stages of the integration process on economic growth are rarely studied. Yet, the analysis of the effects of each phase would avoid economic policy mistakes that can deconstruct not only the economy but also the whole of society and lead to disaster. Thus, what is the contribution of each phase of integration to the economic growth of WAEMU?

The main objective of this article is to empirically determine the effect of the integration process on economic growth. Specifically, it is a question of measuring the interdependence between WAEMU's level of economic integration and its economic growth. The assumption is that the stages of the process of economic integration have a differentiated positive influence on economic growth. An autoregressive vector model was used on data from the Central Bank of West African States, World Development Indicators, and UNCTAD statistics to measure the contribution of the integration process phase to growth. The results show erratic positive effects of the integration phases.

After the introduction, the empirical effects of economic integration are presented first. Second, the methodology and data sources of the study are described. The results and the debates of the results are discussed before the general summary as a conclusion.

\section{Empirical Effects of Economic Integration}

The elimination of any discrimination or barrier between the economies of the member countries and the establishment of a supranational structure is the aim of economic and monetary integration. A government with a tax and economic policy specific to the integration of member countries would then be established. Several intermediate phases exist between the beginnings of the process until the advent of economic integration. Thus, one successively has the zone of free trade, the customs union, the common market, the economic and monetary union, and finally, the political union [2]. The constructive architecture of WAEMU integrates the political union and common market less.

Economic integration processes include positive integration through the harmonisation and coordination of existing economic instruments and negative integration with the removal of all barriers to the movement of goods, services, and factors of production between countries [20]. The channels of transmission 
from the regional economic integration process for growth are generally in a more favourable environment for economic activity [21] [22]. Favourable factors are economies of scale, rapid technological progress, research and development, increased competition, reduction of uncertainty, lower cost of capital due to the integration of financial markets, etc.

Economic growth differs according to the zones of integration. Indeed, the European Union contributes to the growth of 0.6 to 0.8 percentage points. In South America, economic growth went hand in hand with the increase in intra-Mercosur trade, from 10\% to almost 20\% between 1991 and 1994 [10]. With regard to WAEMU, the economic growth rate rose from 5.9\% in 2013 to $6.8 \%$ in 2014.

The fall in tariffs on regional imports has favoured the exports of regional partner countries in the WAEMU zone [23]. With economic governance and convergence, the common market and sectorial policies have had cost-cutting, expansion, increased demand, and common external tariff effects [24]. This results in an increase of intra-regional trade of about $10 \%$ throughout WAEMU. In Burkina Faso, in 2001, the customs union reforms lowered the import tax by $47 \%$ and helped to increase trade by $27.25 \%$, the highest of the WAEMU member countries [25]. Exchanges with the outside are stimulated, and the possible negative effects result from minimised traffic diversions. However, in most WAEMU countries, the observed values of imports and exports with the outside are below expectations [9]. The effects of the WAEMU regional integration on intra-regional trade are being realised with a temporary lag. An increase in imports of $1 \%$ in year $t-1$ would lead to an increase of imports of $0.4 \%$ in year $t$. In addition, trade is more intensive between countries sharing the same land border. A $1 \%$ increase in the importing country's GDP leads to an increase in the partner country's imports of $0.3 \%$ [10].

\section{Methodology}

The effects of regional integration on growth are apprehended by an index of economic integration. The model regressed on the panel data allows the effects of regional integration on the growth in the regions to be analysed separately and jointly [26]. This section presents model, variables, and data sources.

\subsection{Model}

An increased endogenous growth model enhances the phases of the integration process [15]. The model considers the temporal and individual specificities:

$$
Y_{i t}=\beta_{i t}+\Gamma_{i t}(L) Y_{i t}+\varepsilon_{i t},
$$

where $Y_{i t}$ is the dependent variable, $\varepsilon_{i t}$ is the error term, $\Gamma_{i t}(L)$ is a polynomial matrix defined on the delay operator, and $L$ and $\beta_{i t}$ are the period and individual coefficient matrices. The functional form of $\Gamma_{i t}(L)$ is as follows:

$$
\Gamma_{i t}(L)=\beta_{i t}+\Gamma_{i t}^{1} L^{1}+\Gamma_{i t}^{2} L^{2}+\cdots+\Gamma_{i t}^{p} L^{p}+\mu_{i},
$$

with $\Gamma_{i t}^{k} ; k=1$ to $p$. 
The heterogeneity of individuals is considered by the unobservable individual effects $\mu_{i}$ that affect the growth dynamics of the countries. The temporal effects are introduced by temporary dummies variables, $d_{t}$, intended to measure shocks that will uniformly affect all WAEMU countries. A composite error specification is made after the Honda test [27]:

$$
Y_{i t}=\beta_{0}+\Gamma(L) Y_{i t}+d_{t}+\mu_{i}+\varepsilon_{i t} .
$$

The use of least ordinary squares and least generalised squares provides non-convergent intra-individual and inter-individual estimators due to endogeneity [17] [28]. The final theoretical model is as follows:

$$
\widetilde{Y}_{i t}=\Gamma(L) \tilde{Y}_{i t}+\widetilde{\varepsilon_{i t}},
$$

where $\widetilde{Y_{i t}}=\widetilde{Y_{i t}}, \widetilde{Y_{i t^{2}}}, \cdots, \widetilde{Y_{i t^{M}}}$ and $\widetilde{\varepsilon_{i t}}=\widetilde{\varepsilon_{i t^{1}}}, \widetilde{\varepsilon_{i t^{1}}}, \cdots, \widetilde{\varepsilon_{i t^{M}}}$.

Growth is the completion of a production process influenced by trade and investment. Empirically, two models were used to estimate the effects of integration steps on economic growth. The first model seeks to capture the effect of economic integration in general on growth and is written as follows:

$$
Y_{i t}=\left(I C C E_{i t}, V C I_{i t}, T X_{-} I N V_{i t}, T P I B T_{i t}\right),
$$

With TPIBT the growth rate of GDP per capita, $T X \_I N V$ is the investment rate, $V C I$ is the variation of intra-community trade, and $I C C I E$ is the composite index of contribution to economic integration. The second model individually integrates the different phases of the integration process and is written as follows:

$$
Y_{i t}=\left(I C L E_{i t}, I C U D_{i t}, I C U E_{i t}, I C U E T_{i t}, V C I_{i t}, T X_{-} I N V_{i t}, T P I B T_{i t}\right),
$$

where ICLE, ICUD, ICUE, and ICUET are the indices of contribution to free trade, to the customs union, to the economic union, and to the total economic union, respectively. Integration always begins with the free-trade area [2].

Moreover, the stationary with (Im, Pesaran, and Shin tests) analysis shows that all the variables are stationary at level with the exception of stationary $C L E$ and ICUET in the first difference at the level 1 (Table 1).

The information criteria of Akaike (AIC), Schwarz (SC), and Hannan and Quinn (HQ) show an optimal delay of 1 for both models (Table 2).

\subsection{Construction of the Indices}

Economic phenomena are sometimes explained by indices, and the contribution of each phase of the integration process to growth is analysed by indices [29]. The indicator construction technique is based on the work of [30]. A composite index of contribution to economic integration captures the overall contribution of the process to growth [31]. The current economic integration index and the institutional economic integration index refer to the [2] conceptual framework and the theory of optimal currency areas. The index of revealed comparative advantages answers the question of the prediction of international trade flows and is a tool for analysing specialisation models [32]. This index identifies prod- 
ucts, industries, and sectors for which a country has comparative advantages.

The variables used for constructing the indices are grouped into five broad categories. Each of them corresponds to one of the integration phases [33] (Table 3).

\subsection{Data Source}

Estimated data from WAEMU countries cover the period 2000-2013 with 112 observations. They come from the Central bank of west Africa State for sectorial added values (gross fixed capital formation, changes in intra-regional trade, public expenditures, and interest rates) the UNCTAD statistics for the statistics on customs duties, the World Bank for data on the WAEMU Common External Tariff, and GDP per capita growth rates.

\section{Results and Discussion}

This section presents the analysis of the impulse response functions and the decomposition of the variance.

\subsection{Impulse Response Functions}

With respect to the common external tariff, the signing of free-trade agreements

Table 1. Stationarity test results.

\begin{tabular}{cccc}
\hline \multirow{2}{*}{ Variables } & \multicolumn{2}{c}{ Statistics } & \multirow{2}{*}{ Stationarity } \\
\cline { 2 - 3 } & Level & First difference & I $(0)$ \\
TPIBT & $-6.534^{\star}$ & - & I $(0)$ \\
TX_INV & $-6.046^{*}$ & - & I $(0)$ \\
VCI & $-6.643^{*}$ & - & I $(1)$ \\
ICUET & - & $-9.603^{*}$ & I $(0)$ \\
ICUE & $-6.367^{*}$ & - & I (1) \\
ICLE & - & $-10.092^{*}$ & I $(0)$ \\
ICUD & $-6.790^{*}$ & - & I $(0)$ \\
ICCIE & $-2.763^{*}$ & - & \\
\hline
\end{tabular}

*stationary; Authors' own calculation.

Table 2. Optimal delay.

\begin{tabular}{ccccccc}
\hline \multirow{2}{*}{ Delay } & \multicolumn{3}{c}{ Model 1 } & & \multicolumn{3}{c}{ Model 2 } \\
\cline { 2 - 7 } & AIC & SC & HQ & AIC & SC & HQ \\
\hline $\mathbf{1}$ & $10.679^{\star}$ & $11.274^{\star}$ & $10.918^{\star}$ & $-9.317^{\star}$ & $-7.650^{\star}$ & $-8.649^{\star}$ \\
$\mathbf{2}$ & 10.891 & 11.963 & 11.321 & -9.008 & -5.881 & -7.754 \\
$\mathbf{3}$ & 11.146 & 12.695 & 11.767 & -9.085 & -4.500 & -7.247 \\
$\mathbf{4}$ & 11.294 & 13.319 & 12.106 & -8.673 & -2.629 & -6.250
\end{tabular}

$\left.{ }^{*}\right)$ indicates lag order selected by the criterion; Authors’ own calculation. 
Table 3. Integration indices.

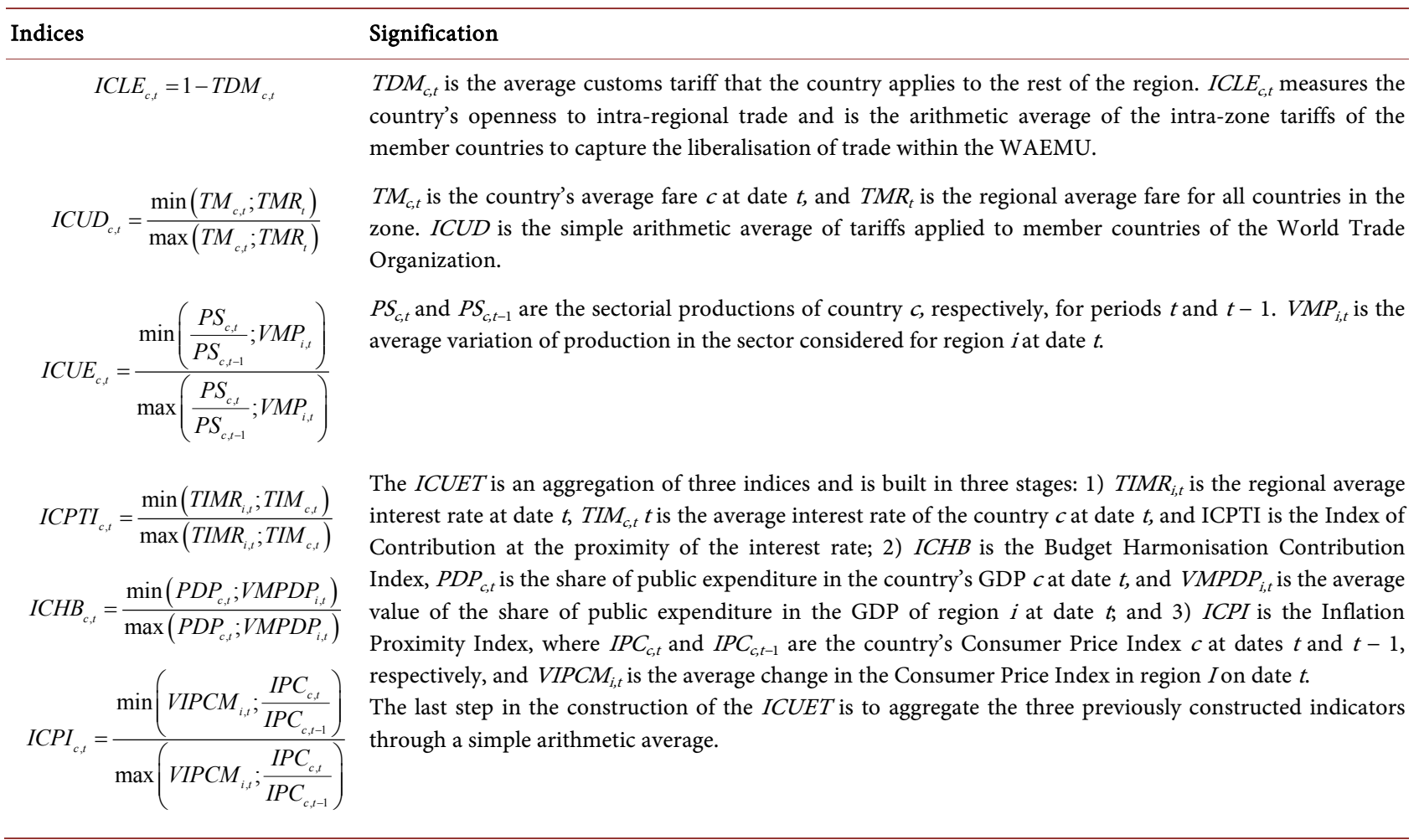

between the WAEMU member countries is a kind of shock to raise the level of indices for each step of integration. The reaction of the growth rate of GDP per capita is observed.

\subsubsection{Economic Integration}

The extreme curves represent confidence intervals at the 5\% threshold, and the middle curve represents the evolution of GDP per capita. The shock of a variable justifies $95 \%$ of the growth behaviour. The shock of economic integration is positive on the GDP per capita growth rate following a shock of the ICCIE variable. This shock has a persistent effect on growth (Figure 1). These results are similar to those of [34] [35], and [36]. Economic integration through trade flows has a significant influence on the growth rate of GDP per capita. On the other hand, according to [37], belonging to an integration zone has no significant effects on economic growth in the case of many regional integration agreements. The effects of the different integration stages on growth in WAEMU are presented in Figure 2.

\subsubsection{Free-Trade Area}

A shock on free trade positively affects much of the economic growth and can be explained by the nature of the products traded in WAEMU (see Figure 2(a)). Intra-regional trade is essentially commodities whose prices fluctuate and depend on the international situation. 


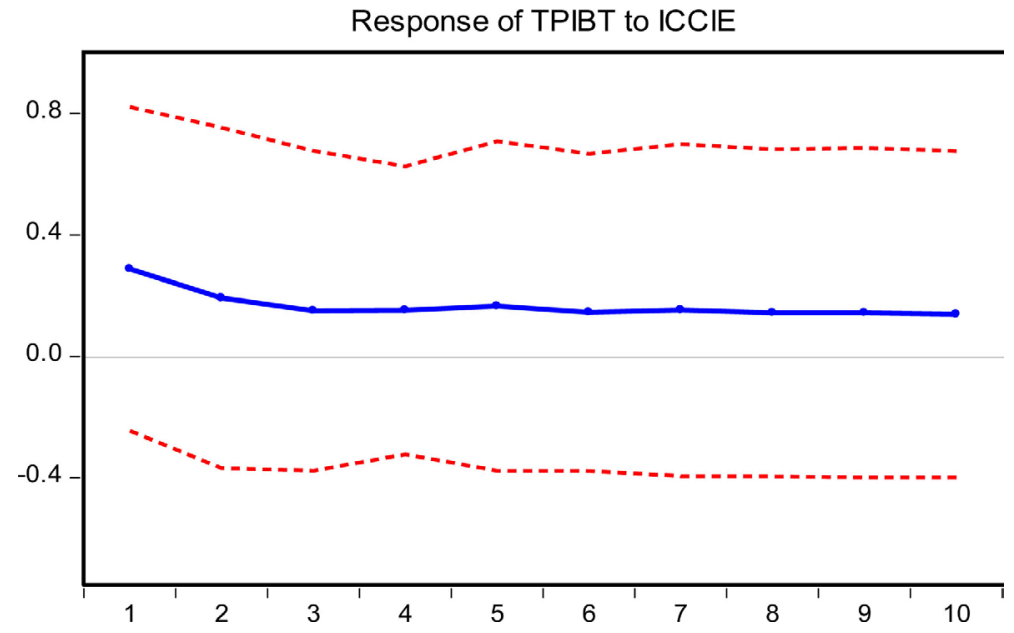

Figure 1. Growth response to a shock on contribution to economic integration (ICCIE).
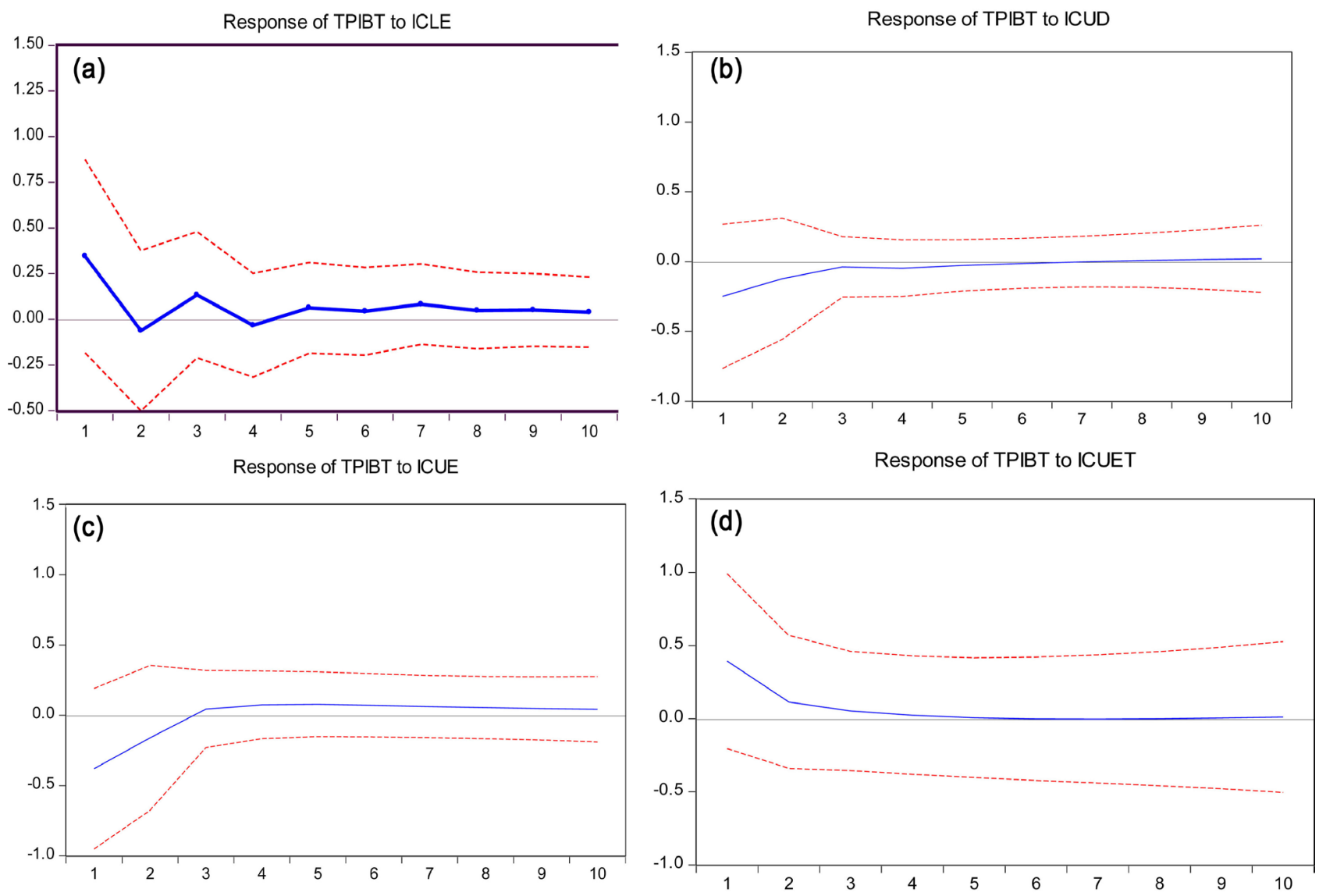

Figure 2. Growth response to a shock of integration steps. Source: Authors' own calculation.

\subsubsection{Customs Union}

The ICUD shock shows a negative dynamic on GDP growth up to the seventh year (see Figure 2(b)). It becomes marginally positive for the rest of the period. Most WAEMU countries derive their income from customs revenue, which is the main explanation for the negative effect. In the short term, this shock causes a loss of income in several WAEMU countries. 


\subsubsection{Economic Union}

The reaction of the GDP per capita following a shock of the economic union is negative the first three years and positive for the rest of the period (see Figure $2(\mathrm{c})$ ). Achieving significant added value requires increased production while controlling production costs through significant equipment investments and acquisition of new production technology.

\subsubsection{Total Economic Union (Economic and Monetary Union)}

The Gross domestic product reacts positively and instantly to the shock of the ICUET. However, this reaction tends to be marginal from the fifth year (see Figure 2(d)). The positive effect is above the adverse effects of the shocks of the economic union and the total economic union. Moreover, the GDP growth following a shock seems to be less strong in the economic and monetary union than in the economic union. Moreover, the decomposition of the variance will make it possible to see the amplitude of the real effect of each variable on growth.

\subsection{Decomposition of the Variance}

The goal of decomposing the variance of the forecast error is to understand its percentage contribution for each stage of the integration process. The part of variation of a system variable explained by another observed variable is analysed by the decomposition of Cholesky.

\subsubsection{Decomposition of Variance Following an Impulse on the ICCIE Variable}

Table 4 indicates that the overall integration effort of a country in the WAEMU zone alone accounts for $0.5 \%$ of the per capita GDP growth of this country in the long term. This result shows the added value of regional integration for WAEMU countries and confirms the response of GDP per capita following the integration shock (Figure 1). It is consistent with those who found that membership of the European community and the free-trade area increases the growth rate from $0.6 \%$ to $0.8 \%$. Contributing shares of the various stages of the integration process are analysed in the following sections.

\subsubsection{Decomposition of Variance Following a Pulse on ICLE, ICUD, ICUE, and ICUET Variables (Tables 5-8)}

Induced growth changes in the free-trade area and the customs union are $2.36 \%$ and $1.66 \%$, respectively. These results are similar to those of [36] on a study

Table 4. Impulse on the composite index of contribution to Economic Integration ICCIE.

\begin{tabular}{cccccc}
\hline Period & S.E. & ICCIE & VCI & TX_D_INVEST & TPIBT \\
\hline 1 & 0.015 & 100 & 0 & 0 & 0 \\
5 & 0.020 & 97.413 & 1.821 & 0.285 & 0.481 \\
10 & 0.020 & 96.618 & 1.858 & 1.018 & 0.505 \\
\hline
\end{tabular}

S.E.: Standard Error; Authors' own calculation. 
Table 5. Impulse of indices of contribution to free trade (ICLE).

\begin{tabular}{ccccccccc}
\hline Period & S.E. & ICLE & ICUD & ICUE & ICUET & VCI & TX_D_INVEST & TPIBT \\
\hline 1 & 0.004 & 100 & 0 & 0 & 0 & 0 & 0 & 0 \\
5 & 0.010 & 53.217 & 20.828 & 2.202 & 13.590 & 1.490 & 4.860 & 3.812 \\
10 & 0.014 & 35.700 & 15.268 & 1.403 & 27.446 & 0.792 & 17.022 & 2.368 \\
\hline
\end{tabular}

Cholesky ordering: ICLE ICUD ICUE ICUET VCI TX_D_INVEST TPIBT. Authors' own calculation.

Table 6. Impulse of ICUD.

\begin{tabular}{ccccccccc}
\hline Period & S.E. & ICLE & ICUD & ICUE & ICUET & VCI & TX_D_INVEST & TPIBT \\
\hline 1 & 0.002 & 0.518 & 99.482 & 0 & 0 & 0 & 0 & 0 \\
5 & 0.002 & 0.757 & 90.648 & 1.065 & 2.754 & 0.426 & 2.682 & 1.668 \\
10 & 0.002 & 0.756 & 88.681 & 1.130 & 3.066 & 0.422 & 4.282 & 1.662 \\
\hline
\end{tabular}

Cholesky ordering: ICLE ICUD ICUE ICUET VCI TX_D_INVEST TPIBT. Authors' own calculation.

Table 7. Impulse of ICUE.

\begin{tabular}{ccccccccc}
\hline Period & S.E. & ICLE & ICUD & ICUE & ICUET & VCI & TX_D_INVEST & TPIBT \\
\hline 1 & 0.036 & 0.106 & 1.705 & 98.188 & 0 & 0 & 0 & 0 \\
5 & 0.040 & 0.424 & 2.586 & 86.487 & 0.701 & 6.835 & 2.764 & 0.202 \\
10 & 0.040 & 0.473 & 2.527 & 84.227 & 1.237 & 6.701 & 4.600 & 0.235 \\
\hline
\end{tabular}

Cholesky ordering: ICLE ICUD ICUE ICUET VCI TX_D_INVEST TPIBT. Authors' own calculation.

Table 8. Impulse of ICUET.

\begin{tabular}{ccccccccc}
\hline Period & S.E. & ICLE & ICUD & ICUE & ICUET & VCI & TX_D_INVEST & TPIBT \\
\hline 1 & 0.044 & 2.709 & 2.651 & 0.529 & 94.112 & 0 & 0 & 0 \\
5 & 0.079 & 5.080 & 1.913 & 1.802 & 90.059 & 0.857 & 0.188 & 0.100 \\
10 & 0.094 & 6.120 & 2.295 & 1.831 & 86.943 & 0.828 & 1.844 & 0.137 \\
\hline
\end{tabular}

Cholesky ordering: ICLE ICUD ICUE ICUET VCI TX_D_INVEST TPIBT. Authors' own calculation.

conducted in Central Africa. As for the economic union and total economic union, their contributions are respectively $0.23 \%$ and $0.14 \%$ in the long term and are specific to the WAEMU zone. The process of economic integration of the WAEMU zone does not respect the classical scheme as advocated by integration theorists [2]. Indeed, the common currency has been the basis for the integration of economic and monetary unions. It was the preliminary step rather than the fifth stage in Balassa's process of economic integration. The order of stages of economic integration affects economic growth.

\section{Conclusions}

The determination of the contribution of each step of the process of economic and monetary integration on the economic growth of the WAEMU was analysed by a model autoregressive vector specified on a panel from 2000 to 2013 . The 
results show that the effect of free trade and customs union on growth are respectively $2.36 \%$ and $1.66 \%$. The economic union and economic and monetary union are two stages of the integration process that have the least effect on growth, with contributions of $0.23 \%$ and $0.14 \%$ respectively. Economic integration explains $0.5 \%$ of the variation of the economic growth of the countries. The establishment of an effective free-trade zone that scrupulously respects the common external tariff set by WAEMU is more beneficial. The mobility of the factors of the production of goods and services has a greater effect on the economies of the countries.

In addition, the common market stimulates trade through the free movement of people, goods, and services to have inclusive and equitable growth, reducing inequalities. Its inclusion in the analysis in the case of data availability would improve the understanding of the contribution of the process of economic and monetary integration. This remains a prospect of future investigation.

\section{Conflicts of Interest}

The authors declare no conflicts of interest regarding the publication of this paper.

\section{References}

[1] Guillaumont, P. (1993) L'intégration économique: Un nouvel enjeu pour la zone franc. Revue Française d'Économie, Hiver.

[2] Balassa, B. (1961) Theory of Economic Integration. Irvin, Homewood, IL.

[3] Lombaerde, P. and Langenhove, L. (2005) Indicators of Regional Integration: Conceptual and Methodological Issues. IIIS Discussion Paper No. 64. https://doi.org/10.2139/ssrn.739711

[4] Carbaugh, J. (2004) International Economics. 9th Edition, Australia. Cited in Negasi, M. (2009) Trade Effects of Regional Integration in Africa: The Case of SADC. Trade and Industrial Policy Strategies, 1-54.

[5] Nuh, R. (2011) The Relationship among Trade Openness, Foreign Direct Investment, Gross Domestic Investment, and Economic Growth in Thailand: 1970-2008. International Islamic University, Islamabad, 1-24.

[6] N’Guessan, K.R. (2018) Intégration financière internationale et croissance économique des pays de la EDEAO: Le rôle de la gouvernance. Journal of Academic Finance, 9, 81-103.

[7] Lamy P. and Gnesotto N. (2018) Où va le monde: Trump et Nous. Ed. Odile Jacob. 249.

[8] Otrou, A.H. (2007) Processus d'intégration régionale et sources de la croissance endogène: Une application aux pays de l'WAEMU. Revue du CAMES, 8, 317-327.

[9] Gbetnkom, D. and Avom, D. (2005) Intégration par le marché: Le cas de l'WAEMU. Région et Développement, No. 22.

[10] Agbodji, A.E. (2007) Intégration et échanges commerciaux intra sous régionaux: Le cas de l'WAEMU. Revue Africaine de I Intégration, 1, 161-188.

[11] Frankel, J. and Rose, A. (1997) Is EMU More Justifiable ex Post than ex Ante? European Economic Review, 41, 753-760. 
[12] Frankel, J. and Rose, A. (1998) The Endogenity of the Optimum Currency Area Criteria. The Economic Journal, 108, 1009-1025. https://doi.org/10.1111/1468-0297.00327

[13] Rose, A.K. (2000) One Money, One Market: The Effect of Common Currencies on Trade. Economic Policy, 15, 8-45. https://doi.org/10.1111/1468-0327.00056

[14] De Nicolò, G. and Juvenal, L. (2014) Financial Integration, Globalization, and Real Activity. Journal of Financial Stability, 10, 65-75. https://doi.org/10.1016/j.jfs.2013.04.004

[15] Inganäs, J. (2014) Regional Integration in West Africa. Are Countries Diverging? Department of Economics, Lund University, Lund.

[16] Nantob, N. (2017) Taxation and Economic Growth in WAEMU Countries: An Empirical Investigation. African Integration and Development Review, 10, 49-86.

[17] Abdoulaye, D. (2017) Droits de propriété, corruption et croissance économique dans les pays de l'WAEMU: Une analyse de la causalité au sens de Granger. African Integration and Development Review, 10, 87-106.

[18] Neto, D.G. and Veiga, F.J. (2013) Financial Globalization, Convergence and Growth: The Role of Foreign Direct Investment. Journal of International Money and Finance, 37, 161-186. https://doi.org/10.1016/j.jimonfin.2013.04.005

[19] Bumann, S., Hermes, N. and Etlensink, R. (2013) Financial Liberalization and Economic Growth: A Meta-Analysis. Journal of International Money and Finance, 33, 255-281. https://doi.org/10.1016/j.jimonfin.2012.11.013

[20] Tinbergen, J. (1954) International Economic Integration. Elsevier, Amsterdam.

[21] Baldwin, R., Martin, P. and Ottaviano, G. (2001) Global Income Divergence, Trade, and Industrialization: The Geography of Growth Take-Offs. Journal of Economic Growth, 6, 5-37. https://doi.org/10.1023/A:1009876310544

[22] Henrekson, M., Torstensson, J. and Torstensson, R. (1997) Growth Effects of European Integration. European Economic Review, 41, 1537-1557. https://doi.org/10.1016/S0014-2921(97)00063-9

[23] Dabene, O. (1995) L’intégration régionale en Amérique Latrine: Le Mercosur. Centre d'Etudes et de Recherches Internationales.

[24] Decaluwe, B., Dissou, Y. and Patry, A. (2001) Union douanière au sein de l'UEMOA une analyse quantitative. Révue Économique, 52, 811-830.

[25] Viner, J. (1950) The Customs Union Issue. Stevens and Sons, Londres.

[26] Njoroge, L.K. (2010) The Impact of Regional Integration on Economic Growth: Empirical Evidence from COMESA, EAC and SADC Trade Blocs. Research Department, Central Bank of Kenya.

[27] Mankiw, G.N., Romer, D. and Weil, D.N. (1992) A Contribution to the Empirics of Economic Growth. The Quarterly Journal of Economics, 107, 407-437. https://doi.org/10.2307/2118477

[28] Honda, Y. (1985) Testing the Error Components Model with Non-Normal Disturbances. The Review of Economic Studies, 52, 681-690. https://doi.org/10.2307/2297739

[29] Sevestre, P. and Trognon, A. (1983) Propriétés de grands échantillons d'une classe d'estimateurs des modèles autorégressifs à erreurs composées. Annales de P Inséé, No. 50, 25-48. https://doi.org/10.2307/20076485

[30] Sevestre, P. (2002) Econométrie des données de panel. Dunod.

[31] Arellano, J. and Bover, O. (1995) Another Look at the Instrumental Variable Esti- 
mation of Error-Components Model. Journal of Econometrics, 68, 29-51. https://doi.org/10.1016/0304-4076(94)01642-D

[32] Dorruci, E., Firpo, S., Fratzscher, M. and Mongelli, F.P. (2002) European Integration: What Lessons for Other Regions? The Case of Latin America. European Central Bank.

[33] Nardo, M., Saisana, M., Saltelli, A., Tarantola, S., Hoffman, A. and Giovannini, E. (2005) Handbook on Constructing Composite Indicators: Methodology and User Guide. OECD (The Statistics Directorate and the Directorate for Science, Technology and Industry) and the Econometrics and Applied Statistics Unit of the Joint Research Centre (JRC) of the European Commission in Ispra, Italy.

[34] Baricako, J., Xavier, G. and Dagba, N. (2013) Construction d'un indice composite d'intégration économique: Le cas de l'Afrique centrale. $\mathrm{X}$ and $\mathrm{Y}$.

[35] De Benedictis, L. and Tamberi, M. (2001) A Note on the Balassa Index of Revealed Comparative Advantage. University of Ancoma, European University Institute.

[36] Alesina, A., Spolaore, E. and Wacziarg, R. (2000) Economic Integration and Disintegration. American Economic Review, 90, 1276-1296.

https://doi.org/10.1257/aer.90.5.1276

[37] De Melo, J., Montenegro, C. and Panagariya, A. (1992) Regional Integration, Old and New. World Bank Policy Research Working Paper, No. 821393.

http://documents.worldbank.org/curated/en/164691468767387570/Regional-integra tion-old-and-new 